\title{
Validation of an educational tool on healthy eating for schoolchildren
}

\section{Validação de uma tecnologia educacional sobre alimentação saudável para escolares}

\author{
Celia Maria Ribeiro de VASCONCELOS ${ }^{1}$ (iD) 0000-0001-9309-4795 \\ Eliane Maria Ribeiro de VASCONCELOS 2 (D) 0000-0003-3711-4194 \\ Maria Gorete Lucena de VASCONCELOS ${ }^{2}$ (D) 0000-0001-7226-1646 \\ Suelen Brito de AZEVEDO² (iD) 0000-0002-0156-7485 \\ Maria Cristina Falcão RAPOSO 3 (D) 0000-0001-7000-3168 \\ Ana Lucia Ribeiro de VASCONCELOS 4 (D) 0000-0002-4075-2210
}

\section{A B S T R A C T}

\section{Objective}

The purpose of this study was to validate the card game The Enigma of the Pyramid about healthy eating, using judges (expert) for the validation of content and design; and the target population (students from the $4^{\text {th }}$ and $5^{\text {th }}$ grades, aged 9-10 years) for the semantic validation (pilot test).

\section{Methods}

The Item-Level Content Validity Index was used to verify the degree of agreement among the experts' opinions, item by item; and the Scale Level Content Validity Index to determine the arithmetic mean of the proportion of items that receive judgments of "non-disagreement" by the judges. The item that obtained Item-Level Content Validity Index greater or equal to 0.80 and Scale Level Content Validity Index greater or equal to 0.90 was considered validated, which was the coefficient of validity. The binominal test was used to select the items that should be revised/modified, using the $p$-value of ratio (reject $\mathrm{H}_{0}$ if $p \leq 0.8$ ). Items were validated at significance level of $\leq 0.05$.

\footnotetext{
1 Instituto Federal de Educação, Ciência e Tecnologia de Pernambuco, Departamento de Ensino. Pesqueira, PE, Brasil. Rod. BR232, Km208, Prado, 55200-000, Pesqueira, PE, Brasil. CMR VASCONCELOS. E-mail: <cmrvasconcelos@gmail.com>. 2 Universidade Federal de Pernambuco, Centro de Ciências da Saúde, Departamento de Enfermagem. Recife, PE, Brasil.

${ }^{3}$ Universidade Federal de Pernambuco, Programa de Pós-Graduação em Estatística, Centro de Ciências Exata e da Natureza, Departamento de Estatística. Recife, PE, Brasil.

${ }^{4}$ Fundação Oswaldo Cruz, Instituto Aggeu Magalhães, Departamento de Saúde Coletiva. Recife, PE, Brasil.
}

\footnotetext{
Como citar este artigo/How to cite this article
}

Vasconcelos CMR, Vasconcelos EMR, Vasconcelos MGL, Azevedo SB, Raposo MCF, Vasconcelos ALR. Validation of an educational tool on healthy eating for schoolchildren. Rev Nutr. 2018;30(5):479-88. http://dx.doi.org/10.1590/167898652018000500005 


\section{Results}

Twenty-two judges and 12 schoolchildren participated in the study. Of the 23 items of the card game, nine were selected for review/modification, of which five were from the language component and four from the suitability component for the target population.

\section{Conclusion}

Once the modifications were made, they were all approved by all participating students, making this educational tool on healthy eating habits available for use with the student population.

Keywords: Food and Nutrition Education. Health Education. Preschool Education.

\section{RE S U M O}

\section{Objetivo}

O objetivo deste estudo foi validar o jogo de cartas "O Enigma da Pirâmide" sobre alimentação saudável, utilizando juízes "especialistas" na validação do conteúdo e aparência; e escolares do $4^{\circ}$ e $5^{\circ}$ ano do ensino fundamental, com idade entre nove e dez anos ("público alvo") na validação semântica (teste piloto).

\section{Métodos}

Utilizou-se o Índice de Validade de Conteúdo em Nível de Item para verificar a congruência de opinião dos juízes, item a item; e o Índice de Validade de Conteúdo em Nível de Escala para determinar à média aritmética da proporção dos itens que receberem avaliação de "não discordância" pelos juízes. Foi considerado aprovado na validação o item que obteve Índice de Validade de Conteúdo em Nível de Item maior ou igual a 0,80 e Índice de Validade de Conteúdo em Nivel de Escala maior ou igual a 0,90, sendo estes os coeficientes de validade. Para selecionar os itens que deveriam ser revisados/modificados utilizou-se o teste binominal, através do valor $p$ da proporção (rejeitando-se a $H_{0}$ se o $p \leq 0,8$ ) - itens validados ao nível de significância $\leq 0,05$.

\section{Resultados}

Participaram do estudo 22 juízes e 12 escolares. Dos 23 itens que compõem o jogo de cartas, nove foram selecionados para revisão/modificação, sendo cinco do componente linguagem e quatro do componente adequação ao público-alvo.

\section{Conclusão}

Realizadas as modificações, foram todas aprovadas, e por todos os alunos participantes, tornando essa ferramenta educativa sobre hábitos alimentares saudáveis disponivel para uso nessa população estudantil.

Palavras-chave: Educação Alimentar e Nutricional. Educação em Saúde. Educação Pré-Escolar.

\section{NTRO D U C T I O N}

Healthy eating habits in childhood are generally maintained by the adult, promoting an appropriate nutritional status for their organic needs [1]. Thus, several countries have developed food guides, using different graphic representations, according to the population to which it was directed (consumers, food industry, nutrition educators) $[2,3]$.

During an intervention study in an elementary school it was found that the students' knowledge and information about food and nutrition, before the educational intervention, were often vague, confused and inaccurate, and sometimes very close to the conceptions formally adopted in the family environment, in groups of friends and in the media, which do not always correspond to healthy eating behaviors [4]. It is within this context that the schools are considered a privileged environment for health education, and for this reason the Programa Saúde na Escola (PSE, School Health Program) was established in 2007, based on a joint-ministerial effort (Ministries of Health and Education), to promote health and prevention of diseases and other health problems, as well as actions related to healthy eating, which provide the students with the opportunity to make 
healthier choices and to be protagonists of the process of their own health $[5,6]$.

Precursor theorists of active methods of education (Piaget, Vigotsky, Elkonin, Huizinga, Dewey, Freinet, Froebel) have emphasized that ludic activities, such as games, provide greater learning, favor moments of relaxation, disinhibition, and promote greater socialization among students, becoming an important pedagogical tool, because it stimulates attention, concentration and interest in the content taught. Using games as a teaching-learning methodology is one strategy that results in greater educational achievement by making lessons dynamic and enjoyable [7].

It has been a challenge to implement actions that promote healthy eating habits in school children, due to the difficulties of parents and the school in offering healthy foods, which denotes the need of the educational process to be a permanent practice, extended to families and communities (schools and household), according to the ministerial recommendation in the PSE, for recognizing that encouraging changes in dietary habits should not be limited to the educational sector, but rather constitute an eminently intersectoral activity $[4,6,8]$.

The use of technological resources that are easy to apply can contribute to the students' education regarding their diet. Positive results have been observed, such as increasing the number of students eating morning meals and raw vegetables [4], and significant improvement in knowledge about healthy eating and acceptance of school meals in an intervention study with games [8]. Based on this assumption, the aim of the present study was to validate the content, design and semantics of an educational card game The Enigma of the Pyramid, to use it as a teaching-learning instrument about healthy eating.

\section{METHODS}

The card game The Enigma of the Pyramid on healthy eating was developed by psychoeducator Toniazzo [9], who authorized its use and allowed modifications, with subsequent validation, to adapt it to the objectives of this study, which is part of a PhD thesis of the Graduate Program in Nursing of the Universidade Federal de Pernambuco (UFPE, Federal University of Pernambuco). Judges were selected for validation of content and design, and the target audience from the $4^{\text {th }}$ and $5^{\text {th }}$ grades of elementary school, aged between nine and ten years, for semantic validation. The modifications were: the addition of 15 "challenge cards", with questions about healthy eating; and 10 "instruction cards", with the theme advocated by the Ministry of Health [10]. The following criteria (Fhering model) were adopted to select the judges: experience in the theme "healthy eating"; and/or expertise in the development of ludic materials [11]. We used the Plataforma Lattes (Lattes Platform) for subject searching, using the keywords: "Nutrition Education AND Healthy Eating AND School" and "Healthy Eating AND School AND Educational Technology", in the scientific production of the following professionals: nutritionists, nurses, pediatricians, pedagogues/educators and designers. The invitation to participate in the study was sent by email. The following documents were sent using Google Drive to those who agreed to participate: invitation letter; Informed Consent Term (ICT); questions related to the professional profile; and the card game The Enigma of the Pyramid. After the 30-day deadline, an additional 10 days was granted; if no replay was received within this period, the judge was replaced. In all, 30 professionals were contacted. The number of judges for validation should range from six to twenty, with at least three specialists from each chosen area of knowledge [12]. For greater reliability, the sample of this study was calculated using the formula: $n=Z^{2} a . P .(1-P) / d^{2}$. $(Z a=$ matched value corresponding to the confidence level $(95 \%) ; p=$ rate of agreement among the judges $(85 \%) ; \quad d=a c c e p t a b l e$ proportion difference among specialists, i.e. the maximum permissible error rate (15\%). Taking into account the above 
recommendation regarding the number of three specialists per area of knowledge, the sample consisted of 22 judges (five nutritionists, five nurses, four pediatricians, four pedagogues/ educator and four designers). As none of the eight designers contacted responded to the invitation, the four vacancies in this category were filled by professionals from other categories who had experience in educational technology and/or in the field of game development. The final sample consisted of the following professionals: six nutritionists; six nurses; four pediatricians; and six pedagogues/educators. The Enigma of the Pyramid is composed of 23 items: three to evaluate content, 12 to evaluate language, four to evaluate the design, and six to assess suitability to the target audience. A space was provided after each item for experts to indicate any changes or write in comments. The items were scored using the Likert Scale $[12,13]$ with the following options: (i) positive ratings: strongly agree (two points), agree (one point); (ii) neutral assessment: neither agree nor disagree (zero points); (iii) negative ratings: disagree (minus one point) and strongly disagree (minus two points).

The degree of agreement among the experts' opinions, item by item, was verified using the Item-Level Content Validity Index (I-CVI) [12-14]. The I-CVI values for an item is the proportion of judges who scored it positively or neutral (nondisagreement). The average proportion (or level) of "non-disagreement" was calculated by the total number of judges and items evaluated. Then, the Scale-Level Content Validity Index (S-CVI) was verified, which corresponds to the arithmetic mean of the proportion of items that received a "non-disagreement" evaluation from the judges. The item was considered approved in the validation if it obtained I-CVI value greater or equal to 0.80 and S-CVI value greater or equal to 0.90 , being these the coefficients of validity $[12,13]$. The binomial test was used, by means of the p-value of the proportion (reject $\mathrm{H}_{0}$ if $p \leq 0.8$ ), to select the items that should be revised/modified (validated items, at significance level $\leq 0.05) \quad[12,13,15]$. The modified items were validated by the target audience, including comprehension and time used to carry out the intervention (pilot test, May 2017, with the participation of the researcher and two research assistants, all documented in the field diary). For the pilot test was randomly selected one school from the municipal schools in Recife and twelve students from that school (six from the $4^{\text {th }}$ grades and six from the $5^{\text {th }}$ grades, initial years) with the following inclusion criteria: regularly enrolled students; aged 9-10 years; literate; and the exclusion criteria were: cognition problems; hearing, visual or communication impairment. An information letter explaining the aim of the research, along with the ICT, was given to these students to obtain consent from their parents or guardians. This study (CAAE: 60824216.8.0000.5208) was approved by the Research Ethics Committee of UFPE (report $n^{\circ} 1.814 .698$ on November 9, 2016) and carried out according to Resolution 466/2012 of the National Health Council.

\section{RE S U L T S}

Most judges (91\%) were women, 64\% had a doctoral degree and 32\% had a master's degree. As for their teaching experience, work experience ranged from five years to 46 years (group mean=22 years), and $82 \%$ of the judges were faculty members of universities. Regarding the development of games and/or other modalities of educational technology, $64 \%$ reported having experience that ranged from six years to 23 years (group mean $=13$ years). Table 1 shows that the card game The Enigma of the Pyramid obtained a validity coefficient considered approved (I-CVI $\geq 0.80$ ) in the 23 evaluated items, and that the average proportion of "non-discordance" among the judges was 0.94 (94\%). Table 2 shows the proportion of "non-disagreement" among judges with the respective S-CVI values, in which the score of "non-disagreement" of 
only three of the 22 judges (judges 4, 11 and 13) was below the validity coefficient considered acceptable (S-CVI $\geq .90)$. The following comments illustrate the satisfaction of most judges: "The cards are well-crafted, and they meet the objectives of the research"; "I have analyzed your instrument in detail and I must praise you for the detail, guidelines and care taken during its development. I believe there shall be fruitful results from it. Successful research!"

From the binomial test (Table 1), nine items were selected for review/modification $\left(\mathrm{H}_{0}\right.$ not rejected at $5 \%$ significance level, i.e., items with $p$-value $>0.05$ ), being five items of the language component $(2.1 ; 2.2,2.8,2.9$, and 2.10) and four being of the suitability component to the target audience (4.1, 4.3, 4.5 and 4.6). In the pilot test with the target population all these items were approved by all participating students. Describing the results per component, according to the score attributed by the judges, Table 2 shows that only four of the 22 judges scored negatively; and Table 1 shows that there was no "disagreement" on the items that deal with the content of the game; and that in the language component, only one item received a positive score from all judges (2.6 which asks if the challenge cards are objective).

Negative scores were assigned as follows: (i) two judges "partially disagreed" in items 2.1 (which asked if the cards referring to each segment of the pyramid are clear); 2.2 (which asked whether these cards were objective); 2.8 (which asked if the rules of the game were clear); and 2.9 (which asked if the rules of the game arouse interest; (ii) there was "partial disagreement" in six items: 2.3 (which asked if the instruction cards were clear); 2.4 (which asked whether instruction cards were objective); 2.5 (which asked if the challenge cards were clear); 2.7 (which asked about the clarity of the rules of the game); 3.3 (which asked if the illustrations were in adequate quantity); and 3.4 (which asked if food illustrations were appropriate for the region); (iii) there were two "partial disagreements" and one "strong disagreement" in four items: 2.10 (which asked if the language of the rules of the game was appropriate for the age group); 4.1 (which asked whether the cards, in each segment of the pyramid, were appropriate for the age group); and regarding to motivation, items 4.5 (which asked if they were appropriate for the age group); and 4.6 (which asked if game aroused interest), (iv) in item 4.3 (which asked if the challenge cards were appropriate for the age group) there was "partial disagreement" and "strong disagreement"; (v) there was a "strong disagreement" in items 4.2 (which asked if the instruction cards were appropriate for the age group) and 4.4 (which asked if the rules of the game were appropriate for the age group). The changes were made on the challenge cards (red stripes were added highlighting who should answer the questions; questions and answers were summarized and adapted for the age group); and instruction cards (regional food illustrations were added, and the texts were summarized and adapted for the age group, aged 9-10 years). During the pilot test, the children were quite motivated, interactive and answered the questions when asked. There was unanimous agreement on all items evaluated.

\section{DISCUSSION}

The term validate means to prove the authenticity of something, making it valid, legitimate, in conditions favorable to the achievement of the objectives proposed [11]. Validation studies are essential to promote the accuracy of the phenomena to be observed. Instruments with high accuracy allows the implementation of appropriate interventions to achieve the expected results [11], which in the present study, the aim was to promote nutrition interventions for healthy eating, according to the PSE in order to prevent diseases such 
Table 1. Validation of educational card game The Enigma of the Pyramid, according to the opinion of the 22 judges, in the subdimensions Content, Language, Appearance and Adequacy, for students in the $4^{\text {th }}$ and $5^{\text {th }}$ year of elementary school. Recife (PE), Brazil, 2018.

1 of 2

\begin{tabular}{|c|c|c|c|c|c|c|c|c|c|}
\hline & \multirow[b]{2}{*}{ Items } & \multicolumn{2}{|c|}{ Disagreement } & \multicolumn{4}{|c|}{ Non-Disagreement } & \multirow[t]{2}{*}{$\mathrm{I}-\mathrm{CVI}$} & \multirow[t]{2}{*}{$p$-value* } \\
\hline & & Total & Partial & $\begin{array}{l}\text { Neither agree } \\
\text { nor disagree }\end{array}$ & Partial & Total & $\sum(\%)$ & & \\
\hline \multirow{3}{*}{ 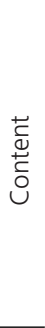 } & $\begin{array}{l}1.1 \text { Is the game in accordance } \\
\text { with the recommendations } \\
\text { of the Ministry of Health on } \\
\text { healthy eating? }\end{array}$ & 0 & 0 & 2 & 7 & 13 & $22(100)$ & 1 & $0.00939^{* *}$ \\
\hline & $\begin{array}{l}\text { 1.2 Do the instruction cards address } \\
\text { the issue of healthy eating? }\end{array}$ & 0 & 0 & 0 & 9 & 13 & $22(100)$ & 1 & $0.00939^{* *}$ \\
\hline & $\begin{array}{l}\text { 1.3 Do the challenge cards address } \\
\text { the issue of healthy eating? }\end{array}$ & 0 & 0 & 0 & 10 & 12 & $22(100)$ & 1 & $0.00939^{* *}$ \\
\hline \multirow{10}{*}{ 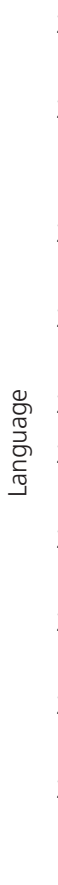 } & $\begin{array}{l}\text { 2.1 Are the cards for each } \\
\text { segment of the pyramid clear? }\end{array}$ & 0 & 2 & 1 & 11 & 8 & $20(90.9)$ & 0.9091 & 0.10000 \\
\hline & $\begin{array}{l}\text { 2.2 Are the cards referring to each } \\
\text { segment of the pyramid } \\
\text { objective? }\end{array}$ & 0 & 2 & 0 & 11 & 9 & $20(90.9)$ & 0.9091 & 0.10000 \\
\hline & $\begin{array}{l}\text { 2.3 Are the instruction cards } \\
\text { clear? }\end{array}$ & 0 & 1 & 2 & 10 & 9 & $21(95.5)$ & 0.9545 & $0.0352^{* *}$ \\
\hline & $\begin{array}{l}\text { 2.4 Are the instruction cards } \\
\text { objective? }\end{array}$ & 0 & 1 & 1 & 12 & 8 & $21(95.5)$ & 0.9545 & $0.0352^{* *}$ \\
\hline & 2.5 Are the challenge cards clear? & 0 & 1 & 1 & 12 & 8 & $21(95.5)$ & 0.9545 & $0.0352^{* *}$ \\
\hline & $\begin{array}{l}\text { 2.6 Are the challenge cards } \\
\text { objective? }\end{array}$ & 0 & 0 & 2 & 11 & 9 & $21(95.5)$ & 0.9545 & $0.0352^{* *}$ \\
\hline & $\begin{array}{l}\text { 2.7 Are the rules of the game } \\
\text { clear? }\end{array}$ & 0 & 1 & 2 & 13 & 6 & $21(95.5)$ & 0.9545 & $0.0352^{* *}$ \\
\hline & $\begin{array}{l}2.8 \text { Are the rules of the game } \\
\text { objective? }\end{array}$ & 0 & 2 & 1 & 13 & 6 & $20(90.9)$ & 0.9091 & 0.1000 \\
\hline & $\begin{array}{l}\text { 2.9 Do the rules of the game } \\
\text { arouse interest? }\end{array}$ & 0 & 2 & 1 & 13 & 6 & $20(90.9)$ & 0.9091 & 0.1000 \\
\hline & $\begin{array}{l}\text { 2.10 Are the rules of the game } \\
\text { appropriate for the age } \\
\text { group? }\end{array}$ & 1 & 2 & 2 & 10 & 7 & $19(86.4)$ & 0.8636 & 0.2267 \\
\hline \multirow{4}{*}{$\frac{5}{\overline{0}}$} & $\begin{array}{l}\text { 3.1 Are the illustrations } \\
\text { compatible with the } \\
\text { content? }\end{array}$ & 0 & 0 & 0 & 9 & 13 & $22(100)$ & 1 & $0.00939^{* *}$ \\
\hline & $\begin{array}{l}\text { 3.2 Are the illustrations adjusted } \\
\text { for the age group? }\end{array}$ & 1 & 0 & 2 & 9 & 10 & $21(95.5)$ & 0.9545 & $0.0352^{* *}$ \\
\hline & 3.3 Are the illustrations adequate? & 0 & 1 & 1 & 9 & 11 & $21(95.5)$ & 0.9545 & $0.0352^{* *}$ \\
\hline & $\begin{array}{l}\text { 3.4 Are food illustrations } \\
\text { appropriate for the region? }\end{array}$ & 0 & 1 & 2 & 13 & 6 & $21(95.5)$ & 0.9545 & $0.0352^{* *}$ \\
\hline \multirow{4}{*}{$\begin{array}{l}\text { 讠 } \\
\frac{0}{2} \\
\frac{0}{0} \\
\frac{d}{0}\end{array}$} & $\begin{array}{l}\text { 4.1 Are the cards for each segment } \\
\text { of the pyramid appropriate } \\
\text { for the age group? }\end{array}$ & 1 & 2 & 4 & 4 & 11 & $19(86.4)$ & 0.8636 & 0.2267 \\
\hline & $\begin{array}{l}\text { 4.2 Are the instruction cards } \\
\text { appropriate for the age group? }\end{array}$ & 1 & 0 & 5 & 8 & 8 & $21(95.5)$ & 0.9545 & $0.0352^{* *}$ \\
\hline & $\begin{array}{l}\text { 4.3 Are the challenge cards appropriate } \\
\text { for the age group? }\end{array}$ & 1 & 1 & 4 & 7 & 9 & $20(90.9)$ & 0.9091 & 0.1000 \\
\hline & $\begin{array}{l}\text { 4.4 Are the rules of the game } \\
\text { appropriate for the age group? }\end{array}$ & 1 & 0 & 4 & 11 & 6 & $21(95.5)$ & 0.9545 & $0.0352^{* *}$ \\
\hline
\end{tabular}


Table 1. Validation of educational card game The Enigma of the Pyramid, according to the opinion of the 22 judges, in the subdimensions Content, Language, Appearance and Adequacy, for students in the $4^{\text {th }}$ and $5^{\text {th }}$ year of elementary school. Recife (PE), Brazil, 2018.

2 of 2

\begin{tabular}{|c|c|c|c|c|c|c|c|c|c|c|}
\hline & \multirow{2}{*}{\multicolumn{2}{|c|}{ Items }} & \multicolumn{2}{|c|}{ Disagreement } & \multicolumn{4}{|c|}{ Non-Disagreement } & \multirow[t]{2}{*}{$\mathrm{I}-\mathrm{CVI}$} & \multirow[t]{2}{*}{$p$-value } \\
\hline & & & Total & Partial & $\begin{array}{l}\text { Neither agree } \\
\text { nor disagree }\end{array}$ & Partial & Total & $\sum(\%)$ & & \\
\hline \multirow{3}{*}{$\begin{array}{l}\frac{\pi}{0} \\
\frac{\pi}{0} \\
\frac{0}{0} \\
\frac{0}{4}\end{array}$} & 4.5 & $\begin{array}{l}\text { Regarding motivation, are } \\
\text { they appropriate for the age } \\
\text { group? }\end{array}$ & 1 & 2 & 4 & 8 & 7 & 19 (86.4) & 0.8636 & 0.2267 \\
\hline & 4.6 & $\begin{array}{l}\text { Regarding motivation, do cards } \\
\text { arouse interest in the game? }\end{array}$ & 1 & 2 & 3 & 9 & 7 & 19 (86.4) & 0.8636 & 0.2267 \\
\hline & & & & & \multicolumn{6}{|c|}{ Média: 0,94 } \\
\hline
\end{tabular}

Note: Validity coefficient Item-Level Content Validity Index (I-CVI) $\geq .80$; "Binomial test, using the means of the $p$-value of the proportion, reject $\mathrm{H}_{0}$ if $p \leq 0.8{ }^{* *}$ Validated Items, at the level of significance $\left.\leq 0.05\right)$; Mean $=\Sigma$ of non-agreement points $(=474) /$ Number of expert judges $(=22) /$ Number of items evaluated (=23); Adopted scores (Likert scale): Strong agreement=2; Partial agreement=1; Neither agree nor disagree=Zero; Partial agreement=minus 1; Strong disagreement=minus 2 .

as obesity and chronic noncommunicable diseases $[5,6]$.

The average proportion of 'non-disagreement' among the judges in the validation of the card game of the present study was 0.94. The substitution of the designer professional did not interfere in the evaluation process presented here, since this professional, in order to ensure the accuracy of the present validation, was replaced by other of the selected professional categories who had experience in active teaching-learning methodologies. In a study that aimed to identify the criteria used to select experts, the following attributes were listed: specialized knowledge and/or skills with extensive experience in the field; and acknowledged competence by peers [11].

The validation of active health education methodologies has been reported by other authors, such as the validation of four educational tools for healthy eating designed for elementary school children which demonstrated that the knowledge acquisition of the participants after the intervention increased $84 \%$ [16] and the validation of the design and content of a serial album on food safety and regional food use, where the overall content validity index of the figures was 0.95 and the script score was 0.98 [17].

Promoting healthy nutrition during childhood is of fundamental importance for the consolidation of adequate eating habits in adulthood [1]. The use of ludic materials, such as games, facilitates learning by providing moments of relaxation and disinhibition to participants $[7,18]$. The school period is considered a strategic moment for the materialization of nutritional guidelines, facilitating the incorporation of healthy eating habits by using active methodologies, in a process of permanent education $[4,18]$. A study found that students exposed a teaching-learning methodology that used board games performed better than the students who had not been exposed to this methodology [18], which corroborates the importance of using games to promote learning. For this reason, also in the spaces for health, active education methodologies have been used to promote health, such as the validation of an educational technology on self-care of women after mastectomy [19]; validation of an educational game about medication administration [20]; validation of a serial album 
Table 2. Validation of the 23 items of educational card game The Enigma of the Pyramid, designed for students in $4^{\text {th }}$ and $5^{\text {th }}$ grades, aged 9-10 years. Proportion of non-disagreement among judges and their respective Scale Level Content Validity Index (S-CVI). Recife (PE), Brazil, 2018.

\begin{tabular}{|c|c|c|c|c|c|c|c|}
\hline \multirow{2}{*}{ Judges } & \multicolumn{2}{|c|}{ Disagreement } & \multicolumn{4}{|c|}{ Non-Disagreement } & \multirow{2}{*}{ S-CVI/AVE } \\
\hline & Strongly disagree & Disagree & Neither agree nor disagree & Agree & Strongly agree & $\sum(\%)$ & \\
\hline 1 & & & & 10 & 13 & $23(100.0)$ & 1 \\
\hline 2 & & & & 6 & 17 & $23(100.0)$ & 1 \\
\hline 3 & & & & 20 & 3 & $23(100.0)$ & 1 \\
\hline 4 & & 6 & 8 & 9 & & $17(73.9)$ & 0.74 \\
\hline 5 & & & & 2 & 21 & $23(100.0)$ & 1 \\
\hline 6 & & & 1 & 22 & & $23(100.0)$ & 1 \\
\hline 7 & & & & 1 & 22 & $23(100.0)$ & 1 \\
\hline 8 & & 1 & & 11 & 11 & $22(95.6)$ & 0.96 \\
\hline 9 & & & & 21 & 2 & $23(100.0)$ & 1 \\
\hline 10 & & & 7 & 13 & 3 & $23(100.0)$ & 1 \\
\hline 11 & & 12 & 1 & 10 & & $11(47.8)$ & 0.48 \\
\hline 12 & & & 8 & 15 & & $23(100.0)$ & 1 \\
\hline 13 & 8 & 5 & & 10 & & $10(43.5)$ & 0.43 \\
\hline 14 & & & 6 & 15 & 2 & $23(100.0)$ & 1 \\
\hline 15 & & & & 17 & 6 & $23(100.0)$ & 1 \\
\hline 16 & & & & & 23 & $23(100.0)$ & 1 \\
\hline 17 & & & & & 23 & $23(100.0)$ & 1 \\
\hline 18 & & & & 23 & & $23(100.0)$ & 1 \\
\hline 19 & & & 2 & 16 & 5 & $23(100.0)$ & 1 \\
\hline 20 & & & & 7 & 16 & $23(100.0)$ & 1 \\
\hline 21 & & & 8 & 10 & 5 & $23(100.0)$ & 1 \\
\hline \multirow[t]{2}{*}{22} & & & & & 23 & $23(100.0)$ & 1 \\
\hline & & & & & & & 20.61 \\
\hline
\end{tabular}

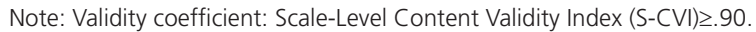

AVE: Average Calculation Method; S-CVI/AVE: Scale-level Content Validity Index, Average Calculation Method.

entitled 'Care in the postpartum period' [21], development and validation of an instrument to evaluate reception with risk classification [14], development and content validation of a predisposition scale to the occurrence of adverse events [15], and development and validation of an educational booklet on venous ulcer care [22]. However, the effectiveness of educational interventions, from the simplest to the most sophisticated, should involve not only the learner, but families and society [23]. The feeding of children and adolescents has been widely discussed in medical and educational areas, due to health problems such as obesity, diabetes, hypertension and various food allergies [24].

\section{CONCLUSION}

The adaptations for the card game The Enigma of the Pyramid were duly validated, and errors of interpretation were removed, making it available for educational activities about healthy eating for public school students aged 9-10 years. The use of games, associated with the 
PSE, is an important tool for primary healthcare teams and education professionals as they provide sustainable actions if they are developed and equally shared with parents, educators and health professionals.

\section{CONTRIBUTORS}

CMRVASCONCELOS and EMRVASCONCELOS contributed to the design of the study, analysis and interpretation of the data; revised and approved the final version of the article. MGL VASCONCELOS and SB AZEVEDO contributed to the revision and approval of the final version of the article. MCF RAPOSO and ALC VASCONCELOS contributed to the analysis and interpretation of the data; reviewed and approved the final version of the article.

\section{ACKNOWLEDGMENT}

The authors thank Maria Regina Toniazzo who granted us the use of the card game about healthy eating The Enigma of the Pyramid, and allowed its modification and validation, which is described in this article.

\section{REFERENCES}

1. Carvalho CA, Fonsêca PC, Priore SE, Franceschini SC, Novaes JF. Food consumption and nutritional adequacy in Brazilian children: A systematic review. Rev Paul Pediatr. 2015;33(2):211-21. http:// dx. doi.org/10.1016/j.rpped.2015.03.002

2. Barbosa RMS, Salles-Costa R, Soares EA. Guias alimentares para crianças: aspectos históricos e evolução. Rev Nutr. 2006:19(2):255-63. http://dx. doi.org/10.1590/S0102-311X2012001300004

3. Molina VT. Guías alimentarias en América Latina: informe de la consulta técnica regional de las Guías Alimentarias. Anal Venezolanos Nutr. 2008 [accesso 2018 jun 7];21(1):31-41. Disponível em: http://www.scielo.org.ve/pdf/avn/v21n1/art06.pdf

4. Zancul MS, Valeta LN. Educação nutricional no ensino fundamental: resultados de estudo de intervenção. Nutrire. 2009 [acesso 2017 ago 16];34(3):125-40. Disponível em: http://files.bvs. br/upload/S/1519-8928/2009/v34n3/a010.pdf
5. Brasil. Ministério da Saúde. Secretaria de Atenção à Saúde. Saúde na escola. Brasília: Ministério da Saúde; 2009 [acesso 2015 out 8]. Disponível em: http://189.28.128.100/dab/docs/publicacoes/ cadernos_ab/abcad24.pdf

6. Malta DC, Silva MMA, Albuquerque GM, Lima CM, Cavalcante T, Jaime PC, et al. A implementações das prioridades da Política Nacional de Promoção da Saúde, um balanço, 2006 a 2014. Ciênc Saúde Coletiva. 2014;19(11):4301-11. http://dx.doi.org/10. 1590/1413-812320141911.07732014

7. Santos CCS, Costa LF, Martins E. A prática educativa lúdica: uma ferramenta facilitadora na aprendizagem na educação infantil. Ensaios Pedag. 2015 [acesso 2018 jun 7]. Disponível em: http:// www.opet.com.br/faculdade/revista-pedagogia/ pdf/n10/ARTIG06.pdf

8. Silva MX, Brandão BCO, Accioly E, Pierucci APTR, Pedrosa $C$. Educação alimentar em escolas públicas pode melhorar o conhecimento sobre alimentação e favorecer a aceitação das refeições planejadas pelo Programa Nacional de Alimentação Escolar? Demetra. 2017;12(4);865-79. http://dx.doi.org/10. 12957/demetra.2017.28204

9. Toniazo MR. Caderno de oficinas saúde integral: programa integração AABB comunidade. 2013 [acesso 2015 out 10]. Disponível em: http://www. aabbcomunidade.org.br/default.php?p=texto. php\&c=cadernos_de_oficinas

10. Brasil. Ministério da Saúde. Secretaria de Atenção à Saúde. Guia alimentar para a população brasileira. 2a ed. Brasília: Ministério da Saúde; 2014 [acesso 2015 abr 8]. Disponível em: http://189.28. 128.100/dab/docs/portaldab/publicacoes/guia_ alimentar_populacao_brasileira.pdf

11. Melo RP, Moreira RP, Fontenele FC, Aguiar ASC, Joventino ES, Carvalho EC. Critérios de seleção de experts para estudos de validação de fenômenos de enfermagem. Rev Rene. 2011 [acesso 2018 maio 12];12(2):424-31. Disponível em: http:// periodicos.ufc.br/rene/article/view/4254/3285

12. Pasquali L. Psicometria. Rev Esc Enferm USP. 2009;43(Spe):992-9. http://dx.doi.org/10.1590/S00 80-62342009000500002

13. Polit D, Hungler B. Fundamentos de pesquisa em enfermagem: métodos, avaliação e utilização. 7a ed. Porto Alegre: Artmed; 2011.

14. Bellucci Júnior JA, Matsuda LM. Construction and validation of an instrument to assess the reception with risk rating. Rev Bras Enferm. 2012;65(5):751-7. http://dx.doi.org/10.1590/S003 4-71672012000500006

15. Lobão WM, Menezes IG. Construction and content validation of the scale of predisposition to 
the occurrence of adverse events. Rev Latinoam Enferm. 2012;20(4):796-803. http://dx.doi.org/10.15 90/S0104-11692012000400021

16. Maia ER, Lima Junior JF, Pereira JS, Eloi AC, Gomes CC, Nobre MMF. Validação de metodologias ativas de ensino-aprendizagem na promoção da saúde alimentar infantil. Rev Nutr. 2012;25(1):79-88. http://dx.doi.org/10.1590/S141 5-52732012000100008

17. Martins MC, Veras JEGLF, Uchoa JL, Pinheiro PNC, Vieira NFC, Ximenes LB. Segurança alimentar e uso de alimentos regionais: validação de um álbum seriado. Rev Esc Enferm USP. 2012;46(6):1354-61. http://dx.doi.org/10.1590/S00 80-62342012000600011

18. Leal JSM, Vieira RHF, Santos AHS, Ferreira SC, Souza DC, Ribeiro L, et al. Produção, aplicação e validação do jogo didático "jogando com os procariotos". Rev Ciênc. 2016 [acesso 2018 mar 9];7(1):169-80. Disponível em: http://biblioteca digital.unec.edu.br/ojs/index.php/revistadeciencias/ article/viewFile/417/630

19. Oliveira MS, Fernandes AFC, Sawada NO. Manual educativo para o autocuidado da mulher mastectomizada: um estudo de validação. Texto Contexto Enferm. 2008;17(1):115-23. http://dx.doi. org/10.1590/S0104-07072008000100013

20. Moreira APA, Sabóia VM, Camacho ACLF, Daher DV, Teixeira E. Jogo educativo de administração de medicamentos: um estudo de validação. Rev
Bras Enferm. 2014;67(4):528-34. http://dx.doi. org/10.1590/0034-7167.2014670405

21. Teixeira E, Martins TDR, Miranda PO, Cabral BG, Silva BAC, Rodrigues LSS. Tecnología educativa acerca de cuidados en el pós-parto: construcción y validación. Rev Baiana Enferm. 2016 [acesso 2018 mar 11];30(2):1-10. Disponível em: https:// portalseer.ufba.br/index.php/enfermagem/article/ view/15358/pdf_53

22. Benevides JL, Coutinho JFV, Pascoal LC, Joventino LC, Martins MC, Gubert FA, et al. Construção e validação de tecnologia educativa sobre cuidados com úlcera venosa. Rev Esc Enferm USP. 2016;50(2):306-12. http://dx.doi.org/10.1590/S00 80-623420160000200018

23. Vasconcelos CMR, Vasconcelos EMR, Vasconcelos MGL, Azevedo SB, Linhares FMP, Leal LP, et al. Intervenções educativas na promoção da alimentação saudável em escolares. Rev Enferm UFPE. 2018;12(10):2803-15.

24. Zompero AF, Lima RMSR, Laburú CE, Frasson F. A educação alimentar e nutricional nos documentos de ensino para a educação básica. Rev Ciênc Ideias. 2015 [acesso 2018 jul 17];6(2):71-82. http://revistascientificas.ifrj.edu.br:8080/revista/ index.php/reci/article/view/376

Received: August 24, 2018

Final version: November 6, 2018 Approved: November 23, 2018 